\title{
CHARGES OVER CHATTELS - ISSUES IN THE FIXED/FLOATING JURISPRUDENCE
}

\author{
Stephen Atherton ${ }^{*}$ and Rizwaan Jameel Mokal**
}

\section{Introduction}

Much of the recent debate as to the criteria which determine whether a charge is properly characterised as fixed or floating has revolved around charges over book debts or other receivables. Charges over chattels have received somewhat less attention, even though an attempt to create a fixed charge over chattels gives rise to interesting questions, some of which do not arise when the collateral consists simply of receivables. While some of these questions have received judicial attention in recent years, others are only now starting to be considered. In this paper, we provide an overview of some of the most important factors which would have to be taken into account when advice is sought as to whether a charge over chattels is fixed or floating. The paper also brings to bear upon this issue principles from other parts of legal doctrine, the relevance of which has not so far been noticed in this context. Where there is a conflict in the authorities, we present our view as to where lies the balance of arguments. We also explain the method to be employed when a debenture is construed in order to determine the proper characterisation of a charge contained in it, paying particular attention to the relevance of the conduct of the parties subsequent to its execution. The paper concludes by summarising our discussion in the form of nine propositions.

In determining whether the provisions contained in a document have created a floating or a fixed charge security over certain assets, it is necessary to establish the essential features of the two species of security.

\section{The essential characteristic of a floating charge}

The classic description of the characteristics of a floating charge is that of Romer LJ in Re Yorkshire Woolcombers Association Limited: ${ }^{1}$

"I certainly do not intend to attempt to give an exact definition of the term 'floating charge', nor am I prepared to say that there will not be a floating charge... which does not contain all the three characteristics that I am about to mention, but I certainly think that if a charge has the three characteristics that I am about to mention it is a floating charge. (1.) If it is a charge on a class of assets of a company present and future; (2.) if that class is one which, in the ordinary course of the business of the company, would be changing from time to time; and (3.) if you find that by the charge it is contemplated that, until some future step is taken by or on behalf of those interested in the charge, the company may carry on its business in the ordinary way as far as concerns the particular class of assets I am dealing with."

\footnotetext{
*Barrister, 3/4 South Square, Gray’s Inn, London.

** Reader in Laws, University College London; Research Associate, Centre for Business Research, Cambridge University. We are very grateful to Look Chan Ho for thoughtful comments.

${ }^{1}$ [1903] 2 Ch 284, at 295.
} 
As explained by Lord Millett, ${ }^{2}$ the first two characteristics referred to by Romer LJ, while typical of a floating charge, do not necessitate the conclusion that the charge is a floating one. It is the third characteristic "which is the hallmark of a floating charge and serves to distinguish it from a fixed charge". As Vaughn Williams LJ stated in the Yorkshire Woolcombers case, ${ }^{3}$

"[W]hat you do require to make a specific security is that the security whenever it has once come into existence, and been identified or appropriated as a security, shall never thereafter at the will of the mortgagor cease to be a security. If at the will of the mortgagor he can dispose of [the asset] and prevent its being any longer a security, although something else may be substituted more or less for it, that is not a 'specific security'."

This approach has received modern confirmation at the highest level. It was followed by Millett LJ in Re Cosslett (Contractors) Limited: ${ }^{4}$

"The essence of a floating charge is that it is a charge, not on any particular asset, but on a fluctuating body of assets which remain under the management and control of the chargor, and which the chargor has the right to withdraw from the security despite the existence of the charge. The essence of a fixed charge is that the charge is on a particular asset or class of assets which the chargor cannot deal with free from the charge without the consent of the chargee. The question is not whether the chargor has complete freedom to carry on his business as he chooses, but whether the chargee is in control of the charged assets."

The same approach was also adopted by the Privy Council in the Brumark case, ${ }^{5}$ which in turn was followed by the House of Lords in Smith (Administrator of Cosslett (Contractors) Limited v Bridgend County Borough Council, where Lord Hoffmann stated: ${ }^{6}$

"[B]ecause the property subject to [the charge in the Cosslett case] (constructional plant, temporary works, goods and materials on the site) was a

\footnotetext{
${ }^{2}$ Agnew v Commissioners of Inland Revenue [2001] 2 AC 710 ("Brumark") at 719G, [13]. Although this is a decision of the Privy Council on appeal from the Court of Appeal of New Zealand, it is highly persuasive authority. While the Court of Appeal in In re Spectrum Plus Limited. [2004] EWCA Civ 670 ("Spectrum") has refused to follow Brumark, it is submitted that this does not detract from the weight of the Privy Council's judgment for the issues at hand, on the following grounds: (1) The ambit of the Spectrum decision is restricted to security over book debts. The effect of the Court of Appeal's decision is merely that a security interest in book debts is capable of being a fixed charge as long as the debenture prohibits the chargor from disposing of the books debts prior to collection, and as long as the chargor, upon collecting the book debts, is required to deposit them in its bank account with the chargee itself. (2) The Court of Appeal in Spectrum considered itself bound by its previous decision in Re New Bullas Trading Limited [1994] 1 BCLC 48. Once again, the effect of this decision is restricted to charges over book debts. (3) The Court of Appeal in Spectrum were not referred to Smith (Administrator of Cosslett (Contractors) Limited v Bridgend County Borough Council [2001] 2 AC 710, a case concerning chattels rather than book debts, where Lord Hoffmann, at [41], approved of the Privy Council's decision; an extract from this passage is provided in the text.

${ }^{3}$ [1903] 2 Ch 284 at 294.

${ }^{4}$ [1998] Ch 495, 510C-D.

5 [2001] 2 AC 710, 721H-722A, [19].

${ }^{6}$ [2002] 1 AC 336, 352, [41].
} 
fluctuating body of assets which could be consumed or... removed from the site in the ordinary course of the [chargor's] business, it was a floating charge".

It follows that a charge is likely to be construed as one floating over a fluctuating body of assets which remain under the management and control of the chargor if the relevant instrument "contemplates that the [debtor] company will from time to time in the future and in the ordinary course of its business change its plant, machinery, fixtures, fittings and ancillary equipment". 7

\section{The essential characteristic of a fixed charge}

As regards the extent to which the chargor must be 'free' to deal with the assets (without recourse to the chargee) such as to indicate that the security created is floating charge security as opposed to fixed charge security, where under the terms of the relevant security the chargor had the freedom (or it is clear that that is what was intended) to deal and dispose of the assets in the ordinary course of business, the charge will be construed as a floating charge as opposed to a fixed charge. ${ }^{8}$ (What constitutes the ordinary course of business is considered below.) However, the existence of certain restrictions on dealing with an asset may not necessarily be inconsistent with a charge being a floating charge. ${ }^{9}$

Similarly, a certain element of control over particular assets on the part of the chargor is not necessarily inconsistent with those assets being subject to a fixed charge. ${ }^{10}$ The existence of a power vested in the chargor to substitute charged property for the purposes of maintenance, alteration or improvement does not necessarily imply that the charge is floating. Authority for this may be found in Holroyd $v$ Marshall $^{11}$ and Seed $v$ Bradley. ${ }^{12}$ However, it is important to note that the chargor's power to remove assets from the security is consistent with the security being a fixed charge only if both of the following conditions are met: (a) the power is limited to the situation where the assets are to be repaired or improved, and (b) the power is one of substitution, or in other words, it consists of a power to remove assets from the

\footnotetext{
${ }^{7}$ Re Armagh Shoes Limited [1984] BCLC 405, per Hutton J at 408E-F. In holding that the deed in that case purporting to create a fixed charge had nevertheless created a floating charge, his Lordship was impressed by the wording of the relevant clause which referred to "all... plant machinery fixtures fittings and ancillary equipment now or at any time hereafter belonging to the mortgagor" (emphasis added). The learned judge concluded, at $419 \mathrm{c}-\mathrm{d}$, that "it is a necessary implication from the deed that the company was to have the right or licence to deal with the assets, comprised within the ambit of the charge, in the ordinary course of its business until the [creditor] decided to enforce the charge."

${ }^{8}$ See for example National Provincial Bank of England Limited v United Electric Theatres Limited [1916] 1 Ch 133, see per Astbury J at 138-139 (the arguments by Counsel for the chargee were also illuminating; see at 135-138), Re Cosslett (Contractors) Limited [1999] Ch 495 at 510, per Millett LJ, and Royal Trust Bank v National Westminster Bank plc [1996] BCLC 682, per Millett LJ at 704 and 706.

${ }^{9}$ Re ASRS Establishment Limited (in Administrative Receivership and in Liquidation) [2000] 2 BCLC 631, per Walker LJ at 637 and 640; Re Cosslett (Contractors) Limited [1998] Ch 495, per Millett LJ at 510; Re GE Tunbridge Limited [1995] 1 BCLC 34, per Sir Mervyn Davies at 39; and Re Brightlife Limited [1987] Ch 200, per Hoffmann J at 209.

${ }^{10}$ The vexed issue of whether, and to what extent, post-contractual conduct might be taken into account in determining the extent of the chargee's control over the collateral is considered in Section 10, below. ${ }^{11}$ (1862) 10 HL Cas 191.

12 [1894] 1 QB 319 (a bill of sale case). See also Coates v Moore [1903] 2 KB 140 (another bill of sale case).
} 
security coupled with a duty to acknowledge that the substitutes of those assets fall within the ambit of the security. ${ }^{13}$

The second condition in particular is crucial to the nature of the fixed charge. The holder of a fixed charge gains an immediate property right in the particular asset subjected to the charge, which is not defeated by the chargor's unilateral attempt to dispose of those assets. ${ }^{14}$ As a result, an asset acquired in substitution for the charged asset is automatically subject, in the chargor's hands, to the property right of the chargee. ${ }^{15}$ The reasoning of the courts in Holroyd and Seed, in insisting upon the need for substituted assets to be considered within the ambit of the security, is based on the recognition of this persistence of the property rights of the fixed charge holder. By contrast, the holder of a floating charge acquires rights in the fund constituted by the relevant assets, and not in any particular asset itself, since his rights "hover" or "float" over the assets until the charge crystallises. ${ }^{16}$ Since the removal in the ordinary course of business of assets from that fund releases them altogether from the rights of the floating charge holder, any assets (or indeed monies) acquired in substitution are not, qua substitutes, covered by the floating charge. ${ }^{17}$ It follows that an agreement by the parties that charged assets may unilaterally be put outside of the security by the chargor and that assets acquired in substitution for them are not to be considered part of the security is inconsistent with their having created a fixed charge, and consistent with their having created a floating charge.

In Re Cimex Tissues Limited, ${ }^{18}$ the company in question had purported to create a fixed charge over the machinery it used to produce toilet rolls, and over a forklift truck specifically modified for use in its business. The badly drafted debenture ${ }^{19}$ appeared to give the company the power to sell, mortgage or otherwise deal with the charged property in the ordinary course of business. The question was whether the charge created was fixed or floating. The court held the charge to be fixed.

In reading the learned judge's decision, it is important to bear in mind the following points. First, the debenture appeared to be internally inconsistent, so that the court had to decide which of its parts reflected the true intentions of the parties. Second, on its proper construction, the debenture did not confer on the company power to deal with ${ }^{20}$ or sell ${ }^{21}$ any part of the charged property without the chargee's consent. However, the judge concluded that even if the company had had a unilateral power to dispose of the charged property, he would have been minded to hold the charge to be fixed rather

\footnotetext{
${ }^{13}$ For Holroyd v Marshall, see per Lord Westbury at 211. For Seed v Bradley, see per Kay LJ at 326.

${ }^{14}$ See e.g. Holroyd v Marshall (1862) 10 HL Cas 191, per Lord Westbury at 211: “... immediately on the new machinery and effects being fixed or placed in the mill, they became subject to the operation of the contract, and passed in equity to the mortgagees..."

${ }^{15}$ See e.g. Foskett v McKeown [2001] 1 AC 102, per Lord Millett at 127.

${ }^{16}$ See e.g. Evans v Rival Granite Quarries Limited [1910] 2 KB 979, 995; Governments Stock and Other Securities Investment Company. v Manila Railway Company [1897] AC 81, 86, and Illingworth $v$ Houldsworth [1904] AC 355, 358.

${ }^{17}$ They might, of course, fall within the defined ambit of the charge in their own right; e.g. where the charge is over 'all machinery from time to time possessed by the chargor', and the substitute assets consist of machinery, or where the machinery is sold for money, and there is a separate floating charge covering money.

${ }^{18}$ [1995] 1 BCLC 409.

${ }^{19}$ See per Burnton QC at [6], [15], [16], etc.

${ }^{20}$ See at [18].

${ }^{21}$ See at [24].
} 
than floating. ${ }^{22}$ All aspects of the judgment dealing with whether the charge could be fixed even though the company had been given the power to remove assets from the ambit of the charge without the chargee's consent therefore constitute obiter dicta. Third, in reaching this decision, the judge was influenced by his reluctance to allow the "unequivocal words of [the relevant clause] explicitly referring to a fixed charge, [to] be overridden by what is in the present debenture a highly ambiguous and uncertain provision for sale...,23

Finally and significantly, the learned judge purported to follow Holroyd v Marshall and Seed v Bradley. However and as already noted, the reasoning of the courts in these cases turned on the chargor's unilateral power being restricted (a) to the circumstances where the charged assets needed to be repaired, maintained or improved, and (b) by an explicit acknowledgement that the substitute assets would fall within the ambit of the charge. Neither of these requirements was in fact satisfied by the debenture before the court. The judge considered this difference to be relevant only as "to the commercial sense of the transaction from the point of view of the chargee, rather than the legal classification of the charge created." ${ }^{24}$ For the reasons explained above, however, it is respectfully submitted that this proposition must be open to considerable doubt. This, coupled with the fact that the discussion concerning the nature of the charge where the chargor has the unilateral power to dispose of the collateral constituted obiter dicta, suggests that the judgment does not constitute even a persuasive authority for the proposition that such a charge may nevertheless be properly characterised as a fixed rather than a floating charge.

\section{The purpose and quality of the chargee's control}

The purpose for which control is exercised over the collateral, the capacity in which the person exercising control does so, and whether he may do so consistently with his other legal obligations, all are crucial factors in determining whether the charge is a fixed one. Let us take these in turn.

In In re Cosslett (Contractors) Limited, ${ }^{25}$ the chargee Council claimed that it had a fixed charge over a coal washing plant by virtue of the fact (among others) that the plant could not be removed from the site without the permission of an engineer, who would make the decision on the basis of whether or not the plant was required for the completion of the works on site. This claim was rejected. It was material to the Court of Appeal's decision ${ }^{26}$ to regard the charge over the coal washing plant as floating that this "restriction [did not] have any relation to the council's security. The council's purpose in imposing the restriction was not to protect its security but to ensure that the company would give proper priority to the completion of the works."27

In Re Double $S$ Printers Limited, ${ }^{28}$ a company had granted a debenture to one of its own directors containing what purported to be a fixed charge over present and future

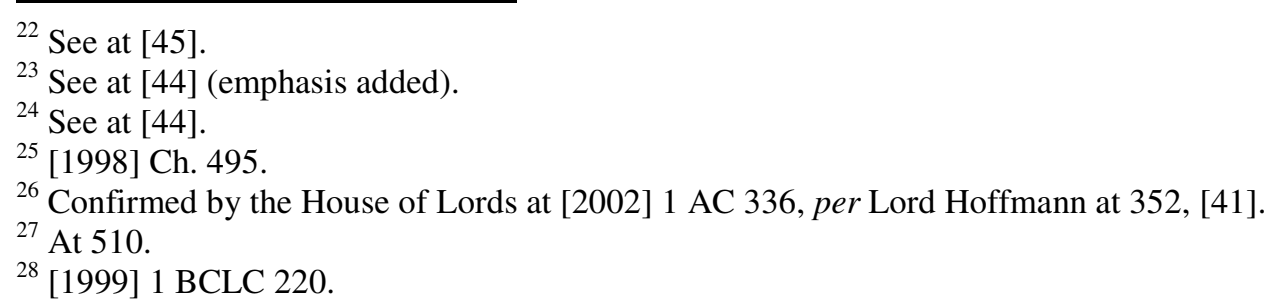


book debts and a floating charge over the rest of its property. Before Jonathan Parker $\mathrm{J}$, the director argued that "the necessary element of control ha[d] at all material times been present de facto in that, as director of the company and one of the two signatories under the company's bank mandate, [the director] at all material times exercised actual control over the book debts". ${ }^{29}$ The court rejected this argument: ${ }^{30}$

"In order for the debenture to take effect as a fixed charge over present and future book debts, there must, it seems to me, be some right of control over the debts, or their proceeds, exercisable by [the director] in his capacity as chargee, and not in some other capacity, e.g. as a director of the company. The opportunity for [the director] to exercise de facto control of the company's bank account in his capacity as a director of the company is, in my view, nihil ad rem... In any event, as a director, [he] was at all material times under a fiduciary duty to the company to act bona fide in the interests of the company, and not for a collateral purpose such as the maintenance of his rights as chargee."

\section{The relevance of the nature of the charged assets}

The nature of the assets sought to be charged is also relevant to the issue of how 'free' the chargor is to deal with those assets, and therefore, to whether the security to which those assets are said to be subject is fixed or floating charge security. ${ }^{31}$ For example, a charge expressed to be a fixed charge over stock in trade or raw materials is normally construed by the courts as being a floating charge. Since the assets in question constitute a highly fluctuating body of assets which will, by necessity, be used, in the sense of being disposed of or consumed, in the ordinary course of the chargor's business, the implication is that the chargor has the ability to deal with the relevant assets in the ordinary course of its business without recourse to the chargee. The courts here are doing no more than recognising the commercial reality of the position: to hold that essentially circulating assets of this sort are subject to a fixed charge would be to require that they could not be used in the chargor's business in the normal way without the chargee's consent, which would result in the paralysis of the former.

Importantly, however, the converse is not true. A charge may be a floating one even though it is over assets which do not form part of the circulating capital of the debtor company. In Re ASRS Establishment Limited (in administrative receivership and liquidation), ${ }^{32}$ the question concerned the status of a purported fixed charge over money held in an escrow account. In confirming Park J's decision at first instance that the charge was floating, Walker LJ on behalf of the Court of Appeal said that " $[t]$ he fact that this particular item was not a regular or reliable source of working capital seems to me irrelevant." ${ }^{33}$ In Cosslett itself, the charge was held to be floating even though it was over (among other things) the coal washing plant which constituted a central part of the chargor's fixed capital structure. ${ }^{34}$

\footnotetext{
${ }^{29}$ [1999] 1 BCLC 220, 224a-b.

30 [1999] 1 BCLC 220, 224b-d (emphasis added).

${ }^{31}$ See Arthur D. Little Limited (in Administration) v Ableco Finance LLC [2002] EWHC 701, [2003] Ch 217; Re Cimex Tissues Limited [1995] 1 BCLC 409.

${ }^{32}$ [2000] 2 BCLC 631.

33 [2000] 2 BCLC 631, 641j.

${ }^{34}$ [2002] 1 AC 336, per Lord Hoffmann at 353, [44].
} 
In ascertaining what, if any, significance is to be accorded to the nature of the assets, helpful guidance is provided by the recent judgment of Etherton $\mathrm{J}$ in Ashborder $B V v$ Green Gas Power Limited. ${ }^{35}$ His Lordship indicated ${ }^{36}$ that in construing whether the chargee has sufficient control over the charged assets for the charge to be considered as fixed, the court will first look at the ordinary and natural meaning of the words in the debenture in order to ascertain whether the chargor has been given a unilateral power to dispose of the assets in the ordinary course of its business. If it has, then the charge is floating, not fixed. It is only if, upon its true construction, the debenture is silent as to whether the chargor has this power that the court will turn to examine the charged assets in order to determine whether or not they fall into a category of assets which could sensibly only have been subjected to a floating charge.

\section{The ambit of the ordinary course of business}

In Ashborder, Etherton $\mathrm{J}$ had to consider whether certain transactions were within the ordinary course of the debtor company's business so as to fall within its power unilaterally to deal with assets subject to the floating charge. His Lordship summarised his examination of English and Commonwealth authorities on the issue thus: ${ }^{37}$

"I do not propose to attempt any particular formulation of the test for determining whether a transaction falls within the ordinary course of a company's business for the purpose of a floating charge, or to make any comprehensive statement of the criteria for determining when a transaction is to be held to have taken place in the ordinary course of business for that purpose. On the other hand, it may be helpful to summarise briefly the following conclusions that I have reached from the decided cases that I have reviewed: (1) The question whether a particular transaction is within the ordinary course of a company's business in the context of a floating charge is a mixed question of fact and law; (2) it is convenient to approach the matter in a two stage process; (3) first, to ascertain, as a matter of fact, whether an objective observer, with knowledge of the company, its memorandum of association and its business, would view the transaction as having taken place in the ordinary course of its business, and, if so (4) second, to consider whether, on the proper interpretation of the document creating the floating charge, applying standard techniques of interpretation, the parties nonetheless did not intend that the transaction should be regarded as being in the ordinary course of the company's business for the purpose of the charge; (5) subject to any such special considerations resulting from the proper interpretation of the charge document, there is no reason why an unprecedented or exceptional transaction cannot, in appropriate circumstances, be regarded as in the ordinary course of the company's business; (6) subject to any such special considerations, the mere fact that a transaction would, in a liquidation, be liable to be avoided as a fraudulent or otherwise wrongful preference of one

\footnotetext{
${ }^{35}$ [2004] EWHC 1517.

36 At [183].

${ }^{37}$ [2004] EWHC 1517, at [227]. It should be noted that in a later hearing, his Lordship gave permission to appeal this aspect of his judgment on the basis that while there was no reasonable prospect of the appeal succeeding, the issues raised were of wide importance and thus would benefit from an examination by the Court of Appeal.
} 
creditor over others, does not, of itself, necessarily preclude the transaction from being in the ordinary course of the company's business; (7) nor does the mere fact that a transaction was made in breach of fiduciary duty by one or more directors of the company; (8) such matters in (6) and (7) may, however, where appropriate and [sic] in all the circumstances, be among the factors leading to the conclusion that the transaction was not in the ordinary course of the company's business; (9) transactions which are intended to bring to an end, or have the effect of bringing to an end, the company's business are not transactions in the ordinary course of its business."

Of particular relevance is his Lordship's treatment of the question whether disposals of assets covered by the charge to raise money towards the continuation of the chargor's business could be regarded as being in the ordinary course: ${ }^{38}$

"The proper starting point is that the words in the expression 'ordinary course
of its... business' are ordinary words of the English language which must be
given the meaning which ordinary business people in the position of [the
parties to the relevant debentures] would be expected to give them against the
factual and commercial background in which those documents were made...
[S]uch businessmen would not be likely to take so narrow a view of 'ordinary
course of business' that it would not embrace a transaction for the preservation
and continuance of a company's business, merely because it was not a
transaction that had ever been carried out before... As Mahoney JA
observed ${ }^{[39]}$, Borax ${ }^{[40]}$ is, indeed, English Court of Appeal authority that a
transaction may be in the ordinary course of business even if it is exceptional
or unprecedented."

It is submitted that the quoted passages have important implications for answering the question whether a charge is fixed or floating. A contention that the nature of the assets charged is such that they would not in the ordinary course of business be disposed of by the debtor company is to be tested as follows. At the first stage, it would have to be ascertained whether "an objective observer with knowledge of the company, its memorandum of association, and its business" might take the view that those assets might be dealt with in the ordinary course of the debtor's business. It would be open to this observer to conclude that it would be in the ordinary course of business of a financially distressed company to raise money in order to continue its business, for example, either (a) when it has several units of the same type of asset, by selling off some units, which sales, while cutting down the debtor company's productive capacity, would allow it to continue operating, or (b) to arrange for a sale and leaseback of some of the charged property. The second stage would involve an examination of the debenture containing the charge which was to be characterised. The process of settling upon its true construction would give require giving due weight to the finding at the first stage as to whether the collateral consists of such assets as were capable of being disposed of in the ordinary course of the chargor's business.

\section{Identifying the charged property}

\footnotetext{
${ }^{38}$ At [202]-[203] and [206].

${ }^{39}$ In Reynolds Brothers (Motors) Pty Limited v Esanda Limited (1983) 8 ACLR 422, 428.

${ }^{40}$ Re Borax Company [1901] 1 Ch 326.
} 
It is essential that the instrument creating a fixed charge identifies the charged property with sufficient specificity. This is important for two reasons. First, the creation of a fixed charge grants an immediate property right in the specific assets charged to the chargee. This carving out and transferring away of property rights from the chargor's title to those assets can only take place if the assets have been identified clearly enough for the instrument to act upon the chargor's title. ${ }^{41}$ Secondly, the existence of a fixed charge requires the chargee to exercise effective control over the charged assets, and in particular, requires it to monitor certain types of dealings with them by the chargor. ${ }^{42}$ Such monitoring cannot take place, and thus, the requisite control cannot be exercised, unless (at the very least) the parties are aware of the identity of assets the chargor's ability to deal with which has been made conditional upon the chargee's consent having been sought and given. ${ }^{43}$

For both these reasons, it follows that where a debenture purports to create a fixed charge over a broadly defined category of assets, it will succeed in doing so only to the extent that the parties identify with sufficient precision, for example through a schedule or register, the particular assets that are to form the subject matter of the grant. $^{44}$

\section{8. 'All or nothing'}

If a clause in a debenture purports to create a fixed charge over assets some of which clearly could not have been intended to be subjected to such a charge, then the entire clause is likely to be interpreted as having created a floating charge. In $\operatorname{Re} G E$ Tunbridge Limited, ${ }^{45}$ a debenture purported to create (among other things) a fixed charge over "[a]ll other assets (not being Floating Assets) now owned or hereafter acquired by the Chargor or in which it now has or in the future acquires an interest" ("the para 2 assets"). Many of these assets ("the auction chattels") had been auctioned by the time that the matter came before the court. In deciding that the charge in fact created was floating and not fixed, Sir Mervyn Davies said: ${ }^{46}$

"I bear in mind that the para 2 assets include not only such assets as the chattels that were sold by auction but also intangible assets such as book debts...I cannot see that the debenture was apt to create a specific charge over the company's book debts... [W] hen one looks at the range of chattels itemised in the auction particulars it is, in my view, unrealistic to suppose that

\footnotetext{
${ }^{41}$ See e.g. Re Goldcorp Exchange Limited (in receivership) [1995] 1 AC 74, per Lord Mustill delivering the Privy Council's advice, at 89-90, and at 95, where the fixed charge case of Holroyd $v$ Marshall (1862) 10 HL Cas 191 is distinguished from the facts before the Privy Council as being "concerned with situations where the goods upon acquisition could be unequivocally identified with the individual contract relied upon." See also Illingworth $v$ Houldsworth [1904] AC 355, per Lord Macnaghten at 358: "A specific charge... is one that without more fastens on ascertained and definite property or property capable of being ascertained and defined."

${ }^{4}$ See e.g. by implication, Brumark [2001] 2 AC 710, 724E-G, [27].

${ }^{43}$ See e.g. National Provincial Bank Limited v United Electric Theatres [1916] 1 Ch 132, per Astbury J at 141; Re G E Tunbridge Limited [1995] 1 BCLC 34, per Sir Mervyn Davies at 39a.

${ }^{4}$ Support for this proposition may be derived from National Provincial Bank $v$ United Electric Theatres Limited [1916] 1 Ch 132 and Re G E Tunbridge Limited [1995] 1 BCLC 34. ${ }^{45}$ [1995] 1 BCLC 34.

${ }^{46}$ Ibid., at 37h, 38b, 38i-39a, and 40a-b.
} 
a considerable number of the auction chattels would not or might not be changed or removed from time to time... My conclusion is that the document as a whole discloses a situation in which a floating charge arises over the para 2 assets..."

In Re ASRS Establishment Limited (in administrative receivership and liquidation), ${ }^{47}$ the Court of Appeal was faced with construing the effect of (among other things) the following clause ("clause 2.1(v)"):

"[ASRS] ... charges by way of fixed charge all book debts, bank account credit balances and other debts and claims now or at any time during the continuance of this security due or owing to [ASRS]..."

At first instance, Park $\mathrm{J}$ had held that the: ${ }^{48}$

"... critical point is that the subparagraph cannot be read so as to create a fixed charge over some of the 'other debts and claims' but a floating charge over others of the 'other debts and claims'. It is all or nothing. Either it creates a fixed charge over all the other debts and claims, or it creates a fixed charge over none of them. I believe that analysis is correct as a matter of construction of the debenture. It is also consistent with the decision of Sir Mervyn Davies in Re G E Tunbridge Limited..."

In the leading judgment in the Court of Appeal, Robert Walker LJ did not consider it necessary to decide the issue. However, his Lordship stated that while he was unable to accept the 'all or nothing' view without reservation, this view is likely to prevail in practice when debentures are construed, "even if it is not requisite as a matter of legal analysis." 49

The 'all or nothing' view is also consistent with Lord Hoffmann's approach in Smith (Administrator of Cosslett (Contractors) Limited) $v$ Bridgend County Borough Council. ${ }^{50}$ The House of Lords here had to decide (among other things) whether a clause created a fixed or a floating charge over a coal washing plant. ${ }^{51}$ It was argued before their Lordships that while the clause "might create a floating charge over materials and small items of plant which were more obviously likely to come and go during the course of a four-year contract, it should be construed as a fixed charge over the washing plant, which was unlikely to be removed and received a separate mention in [a different provision in the debenture.]" ${ }^{, 52}$ Lord Hoffmann rejected this argument on the basis that it was "impossible to construe [the clause] as creating a charge over the washing plant different in nature from that which it created over the other plant and materials brought on site." 53

\footnotetext{
${ }^{47}$ [2000] 2 BCLC 631.

${ }^{48}$ [2000] 1 BCLC 727, 737a-c.

${ }^{49}$ [2000] 2 BCLC 631, at [29-[31].

50 [2001] UKHL 58; [2002] 1 AC 336. The Court of Appeal's decision in In re ASRS Establishment Limited was cited to their Lordships.

${ }^{51}$ The clause may be found at [2002] 1 AC 336, 345-346 at [10].

52 [2002] 1 AC 336, 353 at [44].

${ }^{53}$ Ibid., at 353 at [44]. See also Re Armagh Shoes Limited [1984] BCLC 405, per Hutton J at 419, where his Lordship said, "It was not seriously argued that the charge could be fixed in respect of some
} 


\section{The parties' objective and subjective intentions}

So much for the substance of the distinction between fixed and floating charges. The process of ascertaining the legal nature of a charge begins with the construction of the debenture. ${ }^{54}$ Construction is a matter of mixed fact and law. ${ }^{55}$ It may be approached in two stages which, in this context, were first formalised by Millett LJ in Orion Finance Limited $v$ Crown Financial Management Limited ${ }^{56}$ and authoritatively restated by the Privy Council, speaking through Lord Millett, in Brumark. ${ }^{57}$ The first stage, which we call ascertainment, is concerned with questions of fact, and consists of the construction of the debenture with a view to ascertaining the objective intentions of the parties. ${ }^{58}$ The aim at this stage is not to discover whether the parties subjectively intended to create a fixed or a floating charge. The point, instead, is to identify what rights the parties intended to bestow on each other and by what obligations they intended to be bound (for example, whether the chargor would be required to seek the chargee's consent before engaging in certain types of dealings with the charged assets). The label attached to the charge by the parties provides some, though not particularly probative, evidence as to their intentions. The second stage, which we call categorisation, is concerned with questions of law and operates independently of the parties' intentions. It consists of an analysis of their rights and obligations under the relevant document, as it has been interpreted at the first stage, in order to determine whether the charge created is fixed or floating. Since it is the document as a whole which governs this question, it follows that if, upon its true construction, "the effect of the document as a whole is inconsistent with the terminology which the parties have used, then their ill-chosen language must yield to the substance."59

\section{Post-contractual conduct}

In Brumark, in commenting upon the importance of the chargee's control over the collateral, Lord Millett stated that a requirement that the chargor pays over the proceeds of certain book debts into a blocked account with the charge holder would constitute sufficient control for the charge over those books debts to be characterised as fixed. Lord Millett then went on to say this on behalf of the Privy Council:

of the assets and a floating charge in respect of the remainder of the assets and I consider that there is no basis for such an argument."

54 On contractual interpretation generally, see Investors' Compensation Scheme v West Bromwich Building Society [1998] 1 WLR 896 .

55 "The expression 'construction' as applied to a document... includes two things; first the meaning of the words and secondly their legal effect, or the effect to be given to them. The meaning of the words I take to be a question of fact in all cases, whether we are dealing with a poem or a legal document. The effect of the words used is a question of law", per Lindley LJ in Chatenay v Brazilian Submarine Telegraph Company Limited [1891] 1 QB 79, 85.

${ }^{56}$ [1996] 2 BCLC 78, 84a-e.

57 [2001] 3 WLR 454, 460. This approach has recently been followed by Etherton J in Ashborder BV $v$ Green Gas Power Limited [2004] EWHC 1517 at [163] et seq.; see in particular at [181] and [183].

${ }^{58}$ Objective intentions are those embodied in the words of the relevant document (Smith v Lucas (1881) 18 Ch D 531, 542), the "intentions as expressed" (Inland Revenue Commissioners v Raphael [1935] AC 96, 142).

${ }^{59}$ Orion Finance Limited $v$ Crown Financial Management Limited [1996] 2 BCLC 78, per Millett LJ at $84 \mathrm{e}$. 
"their Lordships would wish to make it clear that it is not enough to provide in the debenture that the account is a blocked account if it is not operated as one in fact. $"$ "60

This dictum, suggesting that enquiries might have to be made not just into the terms of the debenture but also into the way that the account would in fact have been operated, raises interesting questions. It is a well established principle that, in general, any conduct of the parties (whether by words or actions) occurring after entry into an agreement is inadmissible as an aid to construction of that agreement. ${ }^{61}$ It follows that, in general, the conduct of the parties after the execution of the debenture is irrelevant as to the issue whether it creates a fixed or a floating charge. This has been frequently confirmed. ${ }^{62}$ So what is the significance of post-contractual conduct? This Section investigates what Lord Millett might have had in mind when he uttered the dictum noted above. ${ }^{63}$

We suggest that post-contractual conduct can only be relevant to the proper characterisation of a charge in one of five situations. The first two arise where the debenture is alleged to be a sham or a mere pretence, respectively, and in either case, the post-contractual conduct of the parties would be examined in order to ascertain the rights and obligations that they had in fact intended to create. ${ }^{64} \mathrm{~A}$ sham consists of "acts done or documents executed by the parties... which are intended by them to give to third parties or to the court the appearance of creating between the parties legal rights and obligations different from the actual legal rights and obligations (if any) which the parties intend to create." ${ }^{65}$ What is crucial here is that "all the parties thereto must have a common intention that the acts or documents are not to create the legal rights and obligations which they give the appearance of creating." ${ }^{66}$ A mere pretence is also an act done or document executed that does not represent the true nature of the agreement. There is, however, no requirement here that the parties be colluding in order to disguise this nature. It is sufficient that one of the parties intends to do so, with the other merely concurring in the purported terms of the agreement because it does not properly understand them, or because it is driven by circumstances to assent to those terms. ${ }^{67}$ This distinction will be important, for example, where it is the company itself which, wishing unilaterally to dispose of the charged assets, challenges the charge-holder's claim that the charge is a fixed one. An argument on its behalf that the agreement is a sham might be met with the response that it cannot plead its own illegality in asking the court to depart from the explicit terms of the

\footnotetext{
${ }^{60}$ [2001] 2 AC 710, 73B, [48] (added emphasis).

${ }^{61}$ Whitworth Street Estates v Miller [1970] AC 583.

${ }^{62}$ See Re William Gaskell Limited [1994] 1 BCLC 197; Re Armagh Shoes Limited [1984] BCLC 405; and Re Wogan's (Drogheda) Limited [1993] IR 157.

${ }^{63}$ See also the discussion of the "external route" to the interpretation of the parties' agreement in Staughton LJ's judgment in Welsh Development Agency v Export Finance Company Limited [1992] BCLC 148, at 187.

${ }^{64}$ Whether something is a sham or a pretence is a question of pure fact; Bankway Properties Limited $v$ Penfold-Dunsford [2001] EWCA Civ 528, [2001] 1 WLR 1369, per Arden LJ at [52].

${ }^{65}$ Snook v London and West Riding Investments Limited [1967] 2 QB 786, 802 (Diplock LJ).

${ }^{66}$ Ibid.

${ }^{67}$ Antoniades $v$ Villiers [1990] 1 AC 417, 462G-463G (Lord Templeman). For endorsements of this distinction, see e.g. Aslan v Murphy [1989] 3 All ER 130, 133c-h (Lord Donaldson MR, speaking for the Court of Appeal), Burdis v Livsey [2002] EWCA Civ 510, [2003] QB 36, [32] (Aldous LJ, speaking for the Court of Appeal), and Debenhams Retail Plc $v$ The Commissioners of Customs and Excise [2004] EWHC 1540, [112] (Lindsay J).
} 
debenture. ${ }^{68}$ Such a problem would not arise where the chargor can rely on the claim (which in most circumstances would be more appropriate on the facts anyway) that the relevant provisions of the debenture were a pretence, the company's need for funding having rendered it helpless to resist whatever terms might have been imposed upon it by the proposed creditor.

The third situation concerns the claim that the terms of the debenture in question have been varied by the conduct of the parties after its execution, the fourth arises where it is alleged that the benefit of certain of the terms in the debenture has been waived by the appropriate party, and the fifth concerns the situation where one party has become estopped from asserting a certain right. What distinguishes the first two situations where post-agreement conduct is relevant from the remaining three is that, in the former, the conduct of the parties is relevant because it provides evidence as to the intentions of the parties as at the time of entry into the agreement, whereas in the latter, the conduct is examined, insofar as relevant, to throw light on the parties' intentions at the time when they engaged in the relevant conduct.

While variation on the one hand and waiver and estoppel on the other are often treated as identical, the Court of Appeal has recently pointed out that they must be carefully distinguished, since (a) variation by conduct alters the obligations to be performed under the terms of the agreement, whereas waiver and estoppel merely affect the remedies available to the party for the breach of those terms; and (b) variation requires the presence of offer, acceptance and certainty of terms, the usual elements of contract formation, whereas waiver and estoppel do not. ${ }^{69}$

Consider the effect of variation first. Suppose that the debenture on its terms does not allow the chargor the right to engage in unilateral dealings with the collateral, but subsequent to the execution of the debenture, the chargor has openly dealt with the charged assets without the chargee's consent and the latter has continued its lending facilities without raising any objections. If the conditions for an effective variation are satisfied, then the charge, which might properly be characterised as fixed according to the terms of the debenture, ${ }^{70}$ would now fall to be classified as floating. What is more, it is arguable that since this variation by conduct has brought a new (floating) charge into existence, this charge might have to be duly registered. ${ }^{71}$ Failure to register would, on this view, render it void as against the liquidator, administrator or any creditor of the chargor. Note also that, after the variation, if the chargor in the normal course of its business grants property rights in the charged assets to a third party, the latter is unencumbered by the chargee's rights.

The difference in this context between a waiver of the right to veto the removal of an asset from the ambit of the charge, and being estopped from doing so, lies in whether the right to veto is lost permanently, or whether a particular breach of that right is

\footnotetext{
${ }^{68}$ In some situations, the chargee's argument might be defeated on the grounds identified in Tribe $v$ Tribe [1996] Ch 107 .

${ }^{69}$ Glencore Grain Limited v Flacker Shipping Limited (The "Happy Day") [2002] EWCA Civ 1068, [2002] 2 All ER (Comm) 896, [61]-[68].

${ }^{70}$ See above, as to the significance of the chargee's control over the collateral.

${ }^{71}$ Companies Act 1985, s. 395.
} 
accepted ('waived') by the chargee. The former is a case of estoppel, ${ }^{72}$ while the latter is a case of election waiver. Taking estoppel first, suppose that the chargor forms the assumption that it can dispose of some or all of the charged assets without seeking consent from the chargee, and that the chargee has either encouraged this assumption, or knowing about it, has acquiesced in it. This might happen, for example, if the chargor disposes of some part of the collateral openly but without the chargee's consent, and the chargee, through words, actions or omissions, represents to the chargor that it will not seek a remedy either for this violation of the chargee's veto rights over disposal or for similar events in the future, unless it is accompanied or preceded by some other event ('the specified event') (say, the chargor failing to make a loan repayment at the appropriate time). If the chargor significantly alters its position in reliance on this representation, the chargee is henceforth estopped from asserting its right to veto disposals of the collateral by the chargor in the absence of the occurrence of the specified event. Put differently, it has released altogether its right to demand compliance with the provisions in the debenture requiring its consent before the chargor may dispose of the collateral. ${ }^{73}$

The consequences are far-reaching. The chargee has effectively deprived itself of the ability, unless the specified event takes place, to assert the right to control disposals of the charged assets by the chargor, or in other words, to assert the very right which distinguishes a fixed from a floating charge. It must follow, at the point at which this right is lost through estoppel, that the fixed charge ceases to exist, and a floating charge takes its place, which will crystallise at the occurrence of the specified event and at the breach of any of the terms implied into the debenture. Consider the alternative, that the charge remains fixed even though the chargee no longer controls disposals in the normal course of its business by the chargor of the charged assets. This seems clearly inconsistent with the principle in Brumark that the chargee can only claim the benefit of a fixed charge if it in fact exercises such control. ${ }^{74}$ A chargee cannot circumvent this requirement simply by placing itself in a position where it becomes estopped from being able to exercise a monitoring role over the collateral, and thus being required to do so. It also follows therefore that those acquiring rights over the charged assets prior to crystallisation would do so free of the chargee's rights. The floating charge which comes into existence at the point at which the chargee's right to veto disposals of the charged assets is lost by estoppel may also, if appropriate, need to be registered. ${ }^{75}$

Finally, consider waiver: ${ }^{76}$ "the basic proposition is that where two possible remedies or courses of action are open to X [the party which has suffered a breach of a term of

\footnotetext{
${ }^{72} \mathrm{We}$ are concerned with promissory estoppel here, a doctrine whose roots can be traced to the House of Lords' decision in Hughes v Metropolitan Railway Company (1877) 2 App Cas 439, and in modern times, of course to Denning J's judgment in Central London Property Trust v High Trees House [1947] KB 130. It might also be looked at as a case of 'unilateral' or 'forbearance' waiver. Any distinction between estoppel and this type of waiver, which is hard enough to draw in any case (see e.g. HIH Casualty and General Insurance Limited $v$ Axa Corporate Solutions New Hampshire Insurance Company [2002] Lloyd's Rep IR 325), is virtually non-existent in this context.

${ }^{73}$ By analogy, see e.g. Banning $v$ Wright [1972] 1 WLR 972, per Lord Hailsham LC at 97C-D (a case of unilateral or forbearance waiver, which, as noted, is indistinguishable from estoppel in this context). ${ }^{74}$ [2001] 2 AC 710, 73B, [48].

${ }^{75}$ See Companies Act 1985, ss. 395 and 396.

${ }^{76} \mathrm{We}$ are concerned with election waiver here, for the reasons made apparent in the text. Note also that the only waiver relevant in the present context is ex post facto waiver, which happens once the breach
} 
its contract by its counterparty $\mathrm{Y}]$ and $[\mathrm{X}]$ has communicated his intention to follow one course or remedy in such a manner as to lead $\mathrm{Y}$ to believe that his choice has been made, he will not later be permitted to resile from that position" ${ }^{77}$ Note that while silence alone does not constitute waiver, it might do so when viewed in its commercial context, or when it is combined with other contractually significant acts or omissions. ${ }^{78}$ Where property rights in the charged asset are disposed of by the chargor without the chargee's consent, the chargee has a choice (an election) as to whether to resort to the remedies available to it, for example by withholding credit, demanding repayment or appointing a receiver or administrator. Faced with these alternatives, the chargee, explicitly or by continuing to provide credit to the chargor, might be taken to have waived its right to pursue any of these remedies. Since its justification lies in promoting certainty and finality in contractual dealings, the waiver becomes effective immediately, without any need for the chargor to rely on it. ${ }^{79}$

There are two important differences between this type of waiver and estoppel. First, waiver operates only in respect of an individual breach, and the chargee does not lose the ability to insist henceforth on strict compliance with its right to veto disposals of the collateral by the chargor. Of course if the evidence demonstrates a pattern of unilateral dealings with the collateral on part of the chargor followed by 'waivers' of the sort just mentioned, then the proper conclusion might be that the provision requiring the chargee's consent is a sham or a mere pretence, or that the proper interpretation of the parties' dealings is that the chargee has lost its ability to assert this right by variation or estoppel. ${ }^{80}$ Second, a waiver of this sort does not deprive the chargee of all of its rights with respect to the breach, but only those against which it has elected. It is important to notice, therefore, that the chargee might still be able to assert that the person granted property rights in the collateral ('the transferee') as a result of the breach takes subject to the chargee's rights. ${ }^{81}$ Should the chargee be successful in asserting rights against the transferee, the latter may then have a claim against the chargor, for example, for total failure of consideration or breach of contract. In this case and depending upon the correct interpretation of the terms upon which the waiver took place, the chargor might have a claim against the chargee for acting inconsistently with the waiver, or in other words, for approbating and reprobating. ${ }^{82}$

in question (here, disposal of the charged assets without the chargee's consent) has already occurred. Waiver ex ante by the chargee of its right to veto the disposal of the charged assets seems to be indistinguishable from the chargee in fact providing consent to the disposal.

${ }^{77}$ Glencore Grain Limited v Flacker Shipping Limited (The "Happy Day") [2002] EWCA Civ 1068, [2002] 2 All ER (Comm) 896, [65]. See also The Kanchenjunga [1990] 1 Lloyd's Rep 391, per Lord Goff at 397-399.

${ }^{78}$ See e.g. Plasticmoda Societa per Azioni v Davidsons (Manchester) Limited [1952] 1 Lloyd's Rep 527, and Glencore Grain Limited v Flacker Shipping Limited (The "Happy Day") [2002] EWCA Civ 1068, [2002] 2 All ER (Comm) 896, [66].

${ }^{79}$ M.P. Furmston (ed), The Law of Contract (London: Butterworths, 2003) $\left(2^{\text {nd }}\right.$ ed), 298, paragraph 2.108 .

${ }^{80}$ The results flowing from such a conclusion have already been discussed.

${ }^{81}$ This assumes that the transferee cannot claim to be a bona fide purchaser of the legal estate for value. The chargee's ability to claim the assets back from the transferee also assumes that the latter has not changed its position in good faith in reliance on receiving those assets.

${ }^{82}$ See e.g. Craine v Colonial Mutual Fire Insurance Company Limited (1920) 28 CLR 305, 327-328, approvingly referred to in Glencore Grain Limited v Flacker Shipping Limited (The "Happy Day") [2002] EWCA Civ 1068, [2002] 2 All ER (Comm) 896, [65]. 


\section{Conclusion}

The above discussion may be summarised in the following nine propositions:

(1) The characterisation of a charge depends on the proper construction of the instrument creating it. It is the relevant intentions of the parties as encapsulated in the debenture or other instrument creating the charge that matter. The label attached to the charge is just one, fairly weak, bit of evidence as to these intentions. Any intentions alleged to be operating extraneously of the debenture are, in general, irrelevant to proper characterisation.

(2) In general, the conduct of the parties subsequent to the creation of the charge is irrelevant to its true characterisation. However, it may be relevant to determining whether the debenture, taken on its terms, is a sham or a mere pretence, or whether the parties by their conduct have altered the terms of their agreement as enshrined in the debenture, or waived or become estopped from asserting certain of their rights.

(3) The essential characteristic of a floating charge is the chargor's right to put assets beyond the ambit of the charge without the chargee's consent.

(4) The essential characteristic of a fixed charge is the existence of sufficient legal constraints on the chargor's ability to put assets beyond the ambit of the charge without the chargee's consent. Looking at it from the latter's viewpoint, the charge is fixed only if the chargee has sufficient control over the charged assets.

(5) The chargee's control can only be sufficient if it is (a) for the purpose of safeguarding the chargee's security and not merely for some other purpose, (b) not inconsistent with the chargor's legal obligations, and (c) exercised by the chargee in its capacity as chargee, and not in some other capacity.

(6) In construing whether the chargee has sufficient control over the charged assets, the nature of the assets subjected to the charge may be taken into account if the debenture is silent about whether the chargor may unilaterally deal with the assets. The more probable it is that the chargor's business would be paralysed if it were prevented from being able to alienate the charged property in the normal course of business without the chargee's consent, the more probable it is that the parties have created a floating charge, not a fixed one, other things being equal.

(7) In general, the alienation of assets in order to raise finance falls within the normal course of business.

(8) In ascertaining whether the chargee has sufficient control of the charged assets for the charge to be fixed security, the debenture must identify the charged property with sufficient specificity.

(9) If a clause in the debenture purports to create a fixed charge over several categories of asset, some of which clearly could not have been intended to be made subject to a fixed charge, then the entire clause is likely to be interpreted as creating a floating charge. 